\title{
Local Environmental Context Conditions the Impact of Russian Olive in a Heterogeneous Riparian Ecosystem
}

\author{
Graham M. Tuttle, Gabrielle L. Katz, Jonathan M. Friedman, and Andrew P. Norton*
}

\begin{abstract}
Local abiotic and biotic conditions can alter the strength of exotic species impacts. To better understand the effects of exotic species on invaded ecosystems and to prioritize management efforts, it is important that exotic species impacts are put in local environmental context. We studied how differences in plant community composition, photosynthetically active radiation (PAR), and available soil $\mathrm{N}$ associated with Russian olive presence are conditioned by local environmental variation within a western U.S. riparian ecosystem. In four sites along the South Fork of the Republican River in Colorado, we established 200 pairs of plots (underneath and apart from Russian olive) to measure the effects of invasion across the ecosystem. We used a series of a priori mixed models to identify environmental variables that altered the effects of Russian olive. For all response variables, models that included the interaction of environmental characteristics, such as presence/absence of an existing cottonwood canopy, with the presence/absence of Russian olive canopy were stronger candidate models than those that just included Russian olive canopy presence as a factor. Compared with reference plots outside of Russian olive canopy, plots underneath Russian olive had higher relative exotic cover (exotic/total cover), lower perennial C4 grass cover, and higher perennial forb cover. These effects were reduced, however, in the presence of a cottonwood canopy. As expected, Russian olive was associated with reduced PAR and increased N, but these effects were reduced under cottonwood canopy. Our results demonstrate that local abiotic and biotic environmental factors condition the effects of Russian olive within a heterogeneous riparian ecosystem and suggest that management efforts should be focused in open areas where Russian olive impacts are strongest.
\end{abstract}

Nomenclature: Cottonwood, Populus deltoides W. Bartram ex Marshall ssp. monilifera (Aiton) Eckenwalder; Russian olive, Elaeagnus angustifolia L.

Key words: Invader impacts, nitrogen, plant community composition.

Exotic plants have been shown to affect invaded ecosystems by competitively displacing native species, degrading habitat for wildlife, altering nutrient and water cycles, and changing disturbance regimes (e.g., Liao et al. 2008; Vilà et al. 2011). However, these effects vary greatly across ecosystems (Crooks 2002). Parker et al. (1999)

\section{DOI: $10.1614 /$ IPSM-D-16-00029.1}

* First and fourth authors: PhD Candidate and Professor, Department of Bioagricultural Science and Pest Management, Colorado State University, Fort Collins, CO 80523, and U.S. Geological Survey, Fort Collins Science Center, Fort Collins, CO 80526; second author: Assistant Professor, Graduate Degree Program in Ecology, Colorado State University, Fort Collins, CO 80523; and third author: Research Hydrologist, Department of Earth and Atmospheric Sciences, Metropolitan State University of Denver, Denver, CO 80217. Corresponding author's E-mail: Andrew.Norton@Colostate.edu conceptualized the effect of invasive species as a function of range, abundance, and per capita effects. The range and abundance of a species result from its ability to disperse widely and to become established and persist in a range of environments (invasiveness), whereas the per capita effects are a result of its influence on the recipient community (impacts). Much of invasion ecology research has focused on identifying the species traits and environmental characteristics influencing invasiveness of exotic species (e.g., Kolar and Lodge 2001; Levine 2000; Stohlgren et al. 2003), with a recent growing body of research also focused on how traits of invaders influence their impacts (e.g., Barney et al. 2013; Gaertner et al. 2014; Vilà et al. 2011). Less work has focused on identifying how local-scale environmental factors affect the per capita impacts of specific exotic species across environmental gradients or within heterogeneous landscapes (Hulme et al. 2013; Melbourne et al. 2007). This information is crucial for 


\section{Management Implications}

Understanding how invader impacts vary across the landscape is crucial to developing more efficient management strategies. Current strategies primarily treat landscapes as homogeneous; therefore, management efforts are often inefficient because they do not preferentially target the areas of most concern. Using a more targeted management approach, where early intervention is applied only to areas of the landscape likely to experience strong invader impacts, would be much more cost effective. Based on our results, we suggest that ideally Russian olive should be removed from all habitat types because it is associated with an increase in soil $\mathrm{N}$ and proportional exotic plant cover. However, when management funding is limited, we suggest prioritizing control efforts on locations where it is growing in the absence of a cottonwood canopy. In these areas, Russian olive has the largest impact on soil $\mathrm{N}$ and proportional exotic cover. Since Russian olive appears to cause an "invasional meltdown" by facilitating the invasion of other exotic species, particularly in open canopies, research on effects of removal is warranted to see if it reverses Russian olive impacts. If the increased soil $\mathrm{N}$ associated with Russian olive presence persists after the tree's removal, secondary invasion after the disturbance from the removal process is likely. Additionally, favoring cottonwood establishment over Russian olive can be accomplished by promoting flood disturbance by avoiding channel stabilization (i.e., by riprap) and construction.

understanding overall invader impacts and developing effective management strategies (Albers et al. 2010).

Once exotic plants invade an area, their impacts on the recipient ecosystems have been explained in terms of attributes of the invader, characteristics of the recipient community, and local site conditions. One key impact mechanism is the introduction of novel functional traits (e.g., $\mathrm{N}$ fixation) via invasion, which produce impacts by transforming ecosystem dynamics (Ehrenfeld 2010; Strayer 2012). Characteristics of the recipient community (e.g., species, functional group composition, or both) and the invaded site (e.g., climate, soils) also influence the strength of invader impacts (Castro-Díez et al. 2014; Hulme et al. 2013; Maron and Marler 2008; Pyšek et al. 2012). For example, a meta-analysis of factors influencing exotic species impacts by Gaertner et al. (2014) found that the likelihood of invaders causing reinforcing feedbacks (e.g., impacts to soil nutrient cycling) varied based on specific combinations of invader life form and recipient ecosystem. For instance, trees were more likely to affect nutrient dynamics in dunelands than forests. Similarly, Castro-Díez et al. (2014) found that impacts of exotic plants on $\mathrm{N}$ cycling were greatest in warm moist climates and where there were large functional differences between the invader and native species. These recent investigations produced generalizations from meta-analyses of a variety of specific invader-ecosystem combinations (where each invader is present in a single habitat type) but did not examine how impacts of single species vary with environmental context. Focusing on one invader across a heterogeneous environment allows for a clearer understanding of the influence of site conditions on specific invader impacts (Hulme et al. 2013).

Across its entire invaded range and even within a single invaded ecosystem, each invader is likely to encounter heterogeneous biotic communities and abiotic conditions that will influence the type and magnitude of its impact. In a few cases, impacts of single exotic plant species have been shown to vary with environmental conditions, such as precipitation and temperature gradients, and with variations in disturbance regimes or recipient plant community composition (reviewed in Ehrenfeld 2003; Hulme et al. 2013). For example, invasion by the African grass Melinis minutiflora P. Beauv. across an elevation gradient in Hawai' i Volcanoes National Park produced similar changes to fire regimes at all elevations, but the response of native plant communities varied across the elevation gradient due to differences in species and functional group composition (D’Antonio et al. 2000). In New Zealand tussock grasslands, the impact of the exotic forb Hieracium pilosella L. (mouseear hawkweed) on $\mathrm{N}$ mineralization rates was influenced by aspect and recipient community composition (Scott et al. 2001). Understanding the overall impact of an exotic plant species requires assessment of its impact across the range of environmental conditions characteristic of the invaded ecosystem.

We investigated how the impacts of the exotic Russian olive (Elaeagnus angustifolia L.) vary across a heterogeneous western U.S. riparian ecosystem in eastern Colorado. Russian olive is a small deciduous tree in the family Elaeagnaceae. It is actinorhizal, forming a N-fixing symbiosis with actinobacteria in the genus Frankia. Russian olive is currently the fourth most frequently occurring and the fifth most dominant riparian tree species in the western United States (Friedman et al. 2005). First introduced to the United States from western Asia and southern Europe in the early 1900s (Katz and Shafroth 2003), it is now found in all western U.S. states (Friedman et al. 2005) and southern Canadian provinces (Nagler et al. 2011). Based on habitat suitability models, Russian olive is predicted to continue its expansion farther north and west in North America (Jarnevich and Reynolds 2011). The fact that occurrence of naturalized Russian olive is well predicted by nearby occurrence of planted individuals suggests the population is still spreading at the subcontinental scale (McShane et al. 2015). Because of concerns about its potential impacts, Russian olive is classified as a noxious weed in Colorado, New Mexico, Washington, Wyoming, and Connecticut and is a regulated plant in Montana (USDA NRCS 2013). Currently, federal, state, and local land managers have initiated multiple removal projects 
using mechanical and herbicide control techniques (O’Meara et al. 2010).

Russian olive possesses several traits that could cause large impacts on recipient ecosystems. First, as a N-fixing tree invading into ecosystems where this trait is uncommon, the impact of Russian olive on $\mathrm{N}$ cycling is likely to be high (Liao et al. 2008). Rates of $\mathrm{N}$ fixation by Russian olive are higher than rates of all native riparian taxa in the western United States except red alder (Alnus rubra Bong.), and Russian olive leaves contain a higher percent $\mathrm{N}$ and lower $\mathrm{C}: \mathrm{N}$ molar ratios than native cottonwoods (Follstad Shah et al. 2010). Inputs of Russian olive leaf litter causes elevated soil N (Follstad Shah et al. 2010; Simons and Seastedt 1999). Indeed, mineralized soil N levels underneath Russian olive were significantly higher than levels outside its canopy on the Rio Grande in New Mexico (DeCant 2008; Follstad Shah et al. 2010). Second, because seedling recruitment can occur on litter, Russian olive establishes in previously unforested meadows and wetlands not usually suitable for native cottonwood or willow (Salix spp.) recruitment, which need bare soil to germinate (Katz et al. 2001). Third, Russian olive is shade tolerant, allowing it to grow as an understory tree in cottonwood-willow gallery forests of the western Great Plains, where there are few native understory trees (Katz and Shafroth 2003). Because of its abundance in western U.S. riparian ecosystems and concern over its ecological impacts, a growing body of literature assesses the impacts of Russian olive on terrestrial wildlife and aquatic ecosystems (reviewed in Collette and Pither 2015; Katz and Shafroth 2003). However, no published peer-reviewed studies have documented the impact of Russian olive on riparian plant communities. One study, Reynolds and Cooper (2011), examined the effects of Russian olive removal on understory plant communities but did not compare invaded areas to uninvaded reference locations.

Western U.S. riparian systems are ideal for exploring how site characteristics condition invasive species impacts because they have high heterogeneity (Patten 1998), are often heavily invaded (Rood et al. 2010), and are ecologically valuable (Naiman et al. 1993). Riparian systems in the semiarid western United States show high spatial and temporal variation in soil nutrient dynamics (Boggs and Weaver 1994; Vought et al. 1994), soil texture (Lyon and Gross 2005), hydrology (Toner and Keddy 1997), and vegetation patterns (Boggs and Weaver 1994; Lyon and Gross 2005; Wintle and Kirkpatrick 2007) driven by fluvial geomorphic processes (Friedman et al. 1996; Patten 1998). Vertical and horizontal distance from the river channel (thalweg) is responsible for much of the variation in local abiotic and biotic conditions (Merigliano 2005). We tested the influence of physical conditions (e.g., distance to and height above the thalweg, soil texture) and forest canopy (i.e., presence or absence of cottonwood gallery forest overstory) on Russian olive impacts on plant community composition, available soil $\mathrm{N}$, and photosynthetically active radiation (PAR). These environmental variables (physical condition and forest canopy) were chosen to describe the heterogeneity of the riparian landscape because they are important in modifying ecosystem functioning in other semiarid riparian ecosystems (Merigliano 2005; Nakamura et al. 1997). We predicted that Russian olive would be associated with higher proportional exotic plant cover and soil $\mathrm{N}$ and reduced PAR and that these impacts would be conditioned by soil texture and vertical and horizontal distance from the river.

\section{Methods}

Study Area. Our study was located in eastern Colorado at the boundary of the Western Short Grasslands and the Central and Southern Mixed Grasslands ecoregions (Ricketts et al. 1999) in the western Great Plains (Osterkamp et al. 1987). The climate of the Great Plains is characterized by large variation in daily, monthly, and yearly temperature and precipitation; high potential evaporation; and frequent and severe storms (Rosenberg 1986). In the year preceding the 2010 sampling (August 2009 through July 2010), total precipitation was $68.6 \mathrm{~cm}$ (158\% of average). Precipitation in the second year of the study was $56.4 \mathrm{~cm}$ (130\% of average) (Colorado Climate Center 2010).

We selected four sites along an unregulated section of the South Fork of the Republican River in Kit Carson and Yuma Counties, Colorado. The flood of record occurred on this river after heavy thunderstorms on May 30 to 31, 1935. This flood greatly widened the channel and initiated a multidecade period of channel narrowing and establishment of a broad gallery forest of plains cottonwood [Populus deltoides W. Bartram ex Marshall ssp. monilifera (Aiton) Eckenwalder] and peachleaf willow (Salix amygdaloides Anderss.) on the flood-widened channel bed (Katz et al. 2005). These are patchily distributed across the floodplain, with patches ranging from single trees to several hectares in size interspersed with areas of open meadow. Almost all cottonwood recruitment in the study area occurred in the two to three decades following the 1935 flood, and no saplings occurred within our transects. Russian olive first became established in the study area in the 1970s, and it now occurs both in open meadow habitats and in the understory of the cottonwood gallery forest. Few other tree or shrub species are present at these sites, and these are only rarely found. For example, Katz et al. (2005) found that the next most common tree or shrub at our sites, Juniperus virginiana L., represented only $0.6 \%$ of the individual trees or shrubs present in the study area. At each site, Russian olive stands extended at least $100 \mathrm{~m}$ away from the river and at least $400 \mathrm{~m}$ along the river's 


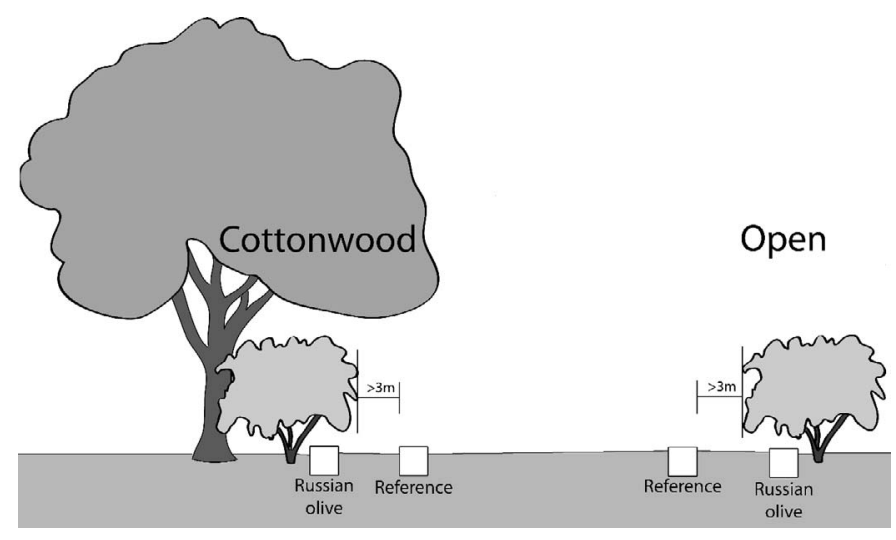

Figure 1. Diagram of two Russian olive and reference plot pairs showing locations underneath cottonwood canopy (cottonwood) or outside the canopy (open). Note that the reference plot for each pair is located either in the open or under cottonwood canopy, depending on where the corresponding Russian olive plot for each pair is located.

length. (See Katz et al. [2005] for a detailed description of the riparian forest at our sites.) All riparian areas used in the study were seasonally grazed.

Study Design and Data Collection. Our four study sites were distributed along an 8-km stretch of the South Fork of the Republican River. We set up 10 transects, two to three per site. Transects originated at the edge of the river and were perpendicular to the active river channel. These extended at least $100 \mathrm{~m}$ from the river bank up to the distal edge of Russian olive stands. Transects were located at least $100 \mathrm{~m}$ apart. Along each transect, we established 40 paired, 1 by $1-\mathrm{m}$ plots (386 in 2010 and 383 in 2011), 20 underneath the canopy of a Russian olive tree (Russian olive plots) and 20 located at least $3 \mathrm{~m}$ from the nearest Russian olive and its canopy drip line (reference plots), at the same height above and distance from the river. The median and 95\% quantile for distance between invaded plots along each transect was $23(7.2$ to 123.01$) \mathrm{m}$. The median distance between an invaded plot and a reference plot was 8.2 (3.5 to 20.86) $\mathrm{m}$. Locating the reference plots at least $3 \mathrm{~m}$ from the Russian olive drip line avoided Russian olive influence on soil N (DeCant 2008) and light. Each plot was further classified as occurring under the cottonwood forest canopy (cottonwood) or in an open grassland area (open) (Figure 1).

Biotic Response Variables (Plant Community Characteristics). To account for the effect of variation in temperature and precipitation on plant growth, we collected plant community data for 2 yr. In late July 2010 and early August 2011, we visually estimated percent cover of each vascular plant species originating in each plot. Plants were identified to species using Weber and Wittmann (2001) and Shaw (2008). We used the U.S. Department of Agriculture PLANTS database (USDA NRCS 2013) for taxonomic nomenclature, classification of each species as exotic or native, and assignment of each species to one of six functional groups: annual grass, annual forb, perennial C3 grass, perennial C4 grass (Shaw 2008), perennial forb, and woody. The low incidence of sedges (Carex spp.) and rushes (Juncus spp.) at our sites prevented the mixed models from converging when these were included as a separate functional group. Consequently, these taxa were combined with perennial C3 grasses for analysis.

Abiotic Response Variables (PAR and Available N). Light intensity (PAR) was measured in July 2010 using a LICOR LI-185 PAR sensor. To determine percent light attenuation, we compared average light intensity values $1 \mathrm{~m}$ above the ground surface in each of the four plot corners and at the center (five readings total) to the light intensity in full sun immediately before sampling in each plot between 8 A.M. and 5 P.M. We used ion exchange resin bags to measure available soil N (Binkley 1984). Nylon mesh bags containing $15 \mathrm{ml}$ of mixed-bed ion-exchange resin were buried at a depth of 5 to $10 \mathrm{~cm}$ in the corner closest to the nearest Russian olive tree in 12 plot pairs (Russian olive/reference) on two transects at each site (192 plots total). One bag was buried in each of the selected plots. The 12 plots represented every other pair of plots along each transect plus the middle and last pairs. Resin bags were buried for 4-mo intervals (August to November, December to March, and April to July). After bags were retrieved from the field, we extracted ions with $75 \mathrm{ml}$ of 2 $\mathrm{M} \mathrm{KCl}$ and measured ammonium $\left(\mathrm{NH}_{4}^{+}\right)$, nitrate $\left(\mathrm{NO}_{3}^{-}\right)$ and nitrite $\left(\mathrm{NO}_{2}^{-}\right)$concentrations using an Alpkem Flow Solution IV Automated wet chemistry system (OI Analytical, College Station, TX) at the Colorado State University Natural Resource Ecology Laboratory.

Environmental Variables. We recorded the location of each study plot to determine its position relative to the present river channel. Plot locations were recorded using a 2012 Trimble GeoExplorer 2008 Series GeoXT GPS connected to an external Trimble Zephyr 2 antenna at $2 \mathrm{~m}$ height. We also recorded the position of the river thalweg (the point of lowest elevation within the active river channel) every $10 \mathrm{~m}$ along the river at each site. We used these coordinates to measure height above $(\mathrm{m})$ and distance from (m) the thalweg for each plot. Russian olive and reference 
Table 1. Weighted AIC scores (relative likelihood of model/sum of relative likelihoods for all models; shown as \%) for a priori selected mixed models describing Russian olive impacts on plant richness, exotic cover, functional group composition, ionic soil $\mathrm{N}$ concentration, and light availability, as conditioned by environmental variables. In all models, Russian olive and Russian olive interaction with each additional term were included. For functional group cover, models all include a functional group interaction for each term included. ${ }^{a}$ For each response variable we considered models with weighted AIC scores greater than $10 \%$. Bold text indicate models with the highest weighted AIC scores.

\begin{tabular}{|c|c|c|c|c|c|c|c|c|c|c|}
\hline Model terms & $\begin{array}{l}\text { Total } \\
\text { cover } \\
2010 \\
\end{array}$ & $\begin{array}{l}\text { Total } \\
\text { cover } \\
2011\end{array}$ & $\begin{array}{l}\text { Rel. } \\
\text { exotic } \\
\text { cover } \\
2010\end{array}$ & $\begin{array}{c}\text { Rel. } \\
\text { exotic } \\
\text { cover } \\
2011\end{array}$ & $\begin{array}{l}\text { Functional } \\
\text { group } \\
\text { composition } \\
2010 \\
\end{array}$ & $\begin{array}{c}\text { Functional } \\
\text { group } \\
\text { composition } \\
2011 \\
\end{array}$ & $\begin{array}{c}\text { Richness } \\
2010\end{array}$ & $\begin{array}{c}\text { Richness } \\
2011\end{array}$ & PAR & oil N \\
\hline Ro & 0.14 & 0.01 & $<0.01$ & $<0.01$ & $<0.01$ & $<0.01$ & 23.54 & 0.34 & $<0.01$ & 3.88 \\
\hline Ro|Cott & 99.56 & 99.73 & 7.44 & 8.55 & 99.99 & 99.99 & 67.27 & 82.53 & 99.99 & 95.61 \\
\hline Ro|Cott + Ro|Dst & $<0.01$ & 0.07 & 0.26 & 0.35 & $<0.01$ & $<0.01$ & 0.03 & 0.03 & $<0.01$ & $<0.01$ \\
\hline $\begin{array}{l}\text { Ro } \mid \text { Cott + Ro|Dst } \\
\quad+\text { Ro|Hgt }\end{array}$ & $<0.01$ & 0.03 & 52.27 & 63.15 & $<0.01$ & $<0.01$ & 0.01 & 0.87 & $<0.01$ & $<0.01$ \\
\hline Ro $\mid$ Cott + Ro $\mid S d$ & 0.09 & 0.15 & 3.51 & 3.31 & $<0.01$ & $<0.01$ & 0.34 & 0.37 & $<0.01$ & 0.09 \\
\hline $\begin{array}{l}\text { Ro|Cott }+ \text { Ro|Dst } \\
\quad+\text { Ro|Hgt }+ \text { Ro|Sd }\end{array}$ & $<0.01$ & $<0.01$ & 33.33 & 23.23 & $<0.01$ & $<0.01$ & $<0.01$ & $<0.01$ & $<0.01$ & $<0.01$ \\
\hline Ro|Dst & $<0.01$ & $<0.01$ & $<0.01$ & $<0.01$ & $=0.0$ & $<0.0$ & $<0.01$ & $<0.01$ & $<0.01$ & $<0.01$ \\
\hline Ro|Dst + R & $<0.01$ & $<0.01$ & 0.10 & 0.05 & $<0$ & $<0.0$ & $<0.01$ & $<0.01$ & $<0.01$ & $<0.01$ \\
\hline $\begin{array}{l}\text { Ro|Dst }+ \text { Ro|Hgt } \\
\quad+\text { Ro|Sd }\end{array}$ & $<0.01$ & $<0.01$ & 0.06 & 0.02 & $<0.01$ & $<0.01$ & $<0.01$ & $<0.01$ & $<0.01$ & $<0.01$ \\
\hline $\mathrm{RolH}$ & & 0 & 3.0 & & & & & 15 & 1 & 0.87 \\
\hline Ro|Sd & $<0.01$ & $<0.01$ & $<0.01$ & $<0.01$ & $<0.01$ & $<0.01$ & 0.14 & $<0.01$ & $<0.01$ & $<0.01$ \\
\hline
\end{tabular}

${ }^{a}$ Abbreviations: AIC, Akaike information criterion; Rel., relative; PAR, photosynthetically active radiation; Ro, underneath or outside Russian olive canopy; Cott, underneath or outside cottonwood canopy; Dst, distance to thalweg; Hgt, height above thalweg; Sd, percent sand.

plots were a similar distance from (mean \pm SEM; $185.1 \pm$ $10.1 \mathrm{~m}$ vs. $\left.182.4 \pm 10.2 \mathrm{~m}, t_{306}=-0.19, \mathrm{P}=0.85\right)$ and height above the thalweg $(1.91 \pm 0.08 \mathrm{~m}$ vs. $1.95 \pm 0.08$ $\mathrm{m}, t_{306}=0.37, \mathrm{P}=0.71$ ). Of the 386 plots used in our analysis, 248 occurred outside of the cottonwood canopy (open) and 138 occurred underneath the cottonwood canopy (cottonwood). Compared with cottonwood plots, open plots tended to occur farther from the channel (213.2 $\pm 8.8 \mathrm{~m}$ vs. $\left.136.9 \pm 11.1 \mathrm{~m}, t_{306}=5.41, \mathrm{P}<0.01\right)$ and at a lower height above the channel $(1.76 \pm 0.07 \mathrm{~m}$ vs. 2.19 $\left.\pm 0.09 \mathrm{~m}, t_{306}=-3.51, \mathrm{P}<0.01\right)$.

We measured soil texture in the 192 plots where we deployed resin bags. At each plot, we collected soil cores from each of the three corners without a resin bag using a 2 by $30-\mathrm{cm}$ soil probe. The three soil cores were then aggregated for each plot. We then used the hydrometer method (Bouyoucos 1936) to measure soil texture (\% sand, silt, clay) on a 40-g dried and sieved subsample. Because all three soil textures were highly correlated (data not shown), we only included percent sand in our statistical analyses. Percent sand in the plots ranged from 17.5 to $96.3 \%$. Russian olive plots had similar percent sand to reference plots $\left(62.9 \% \pm 2.2\right.$ vs. $62.6 \% \pm 2.2, t_{146}=-0.11, \mathrm{P}=$ $0.91)$. Open plots tended to have higher percent sand than cottonwood plots $\left(67.2 \% \pm 1.9\right.$ vs. $56.2 \% \pm 2.3, t_{146}=$ 3.63, $\mathrm{P}<0.01)$.

Statistical Analysis. We used the SAS $9.3^{\circledR}$ MIXED procedure (2012, SAS Institute, Cary, NC) to run several a priori general linear mixed models to identify environmental variables that conditioned the impact of Russian olive on plant community structure, PAR, and soil N. Our set of candidate models all contained Russian olive canopy (categorical: presence/absence) as a fixed factor, plus other variables previous research has shown were important modifiers of semiarid riparian ecosystems (e.g., Bagstad et al. 2006; Bechtold and Naiman 2006; Merigliano 2005). Thus, the candidate models were designed to determine which environmental factor or factors were associated with greater or lesser effects of Russian olive (Table 1). Fixed factors examined in the models were presence of cottonwood overstory (categorical: cottonwood/open), soil percent sand (continuous), distance to and elevation above thalweg (both continuous), and the interaction of each of 
these variables with Russian olive. Because an Akaike information criterion (AIC) model selection approach requires that only a limited set of a priori models be examined, we did not examine all possible combinations of environmental variables with and without Russian olive and instead focused our models on those that could test whether or not Russian olive's effect on the response variables was modified by other environmental factors. Within any one model, evidence for effect modification is a significant interaction between Russian olive and an environmental variable. The response terms used in the models were relative PAR (measured in July 2010), total available soil N concentration (for August 2010 through July 2011), total plant cover in 2010 and 2011, relative exotic plant cover (exotic/total cover) in 2010 and 2011, plant species richness in 2010 and 2011, and plant functional group cover in 2010 and 2011. Separate models were run for each year of data collection.

Plant functional group cover was modeled using a repeated measures structure (Holland 2006). To do this, we created a "functional group" class variable and added it, along with an interaction with every other fixed effect, into the model structure used above. This variable was the repeated factor, and a heterogeneous compound symmetric covariance structure was used to account for a lack of independence among functional groups. This covariance structure produced the lowest AIC values of the structures tested (variance components, compound symmetric, heterogeneous compound symmetric, and unstructured).

Using a single model for functional cover each year allowed us to compare overall differences in functional group composition and differences between specific functional groups. The SAS SUBJECT option was used to ensure that a plot remained the unit of replication. Available soil $\mathrm{N}$ concentrations and plant functional cover data were $\ln +0.01$-transformed and total plant cover was square root-transformed to better meet the model assumptions of normality and homoscedasticity.

To assess model strength, we compared weighted AIC scores between models that added additional environmental factors and their interaction with Russian olive presence as fixed factors. A weighted AIC score is calculated by dividing the relative likelihood of each model by the sum of the relative likelihoods for all candidate models. A weighted AIC score can be interpreted as the probability that a selected model is the best model (minimizes KullbackLeibler discrepancy; Burnham and Anderson 2002). To keep comparisons of weighted AIC scores consistent between models, we used a dataset that eliminated any plots with missing values for any of the explanatory variables. Once we selected models for each of the eight response variables, we used $F$ tests on the full datasets to identify significant factors within the selected model and performed $t$ tests to compare least squares means between groups. If the selected model had a weighted AIC value below 90\% (Johnson and Omland 2004), we also examined any other models with weighted AIC score values greater than $10 \%$. We did not adjust our $\mathrm{P}$ values for multiple tests, because such adjustments make P values a function of the number of tests conducted. Determining how many tests to include in an adjustment is arbitrary, making adjusted $\mathrm{P}$ values difficult to interpret (Gotelli and Ellison 2004).

\section{Results}

Environmental Influence on Russian Olive Effects. Presence of Russian olive was associated with a higher proportion exotic plant cover, perennial forb cover, and soil $\mathrm{N}$ concentration and a lower perennial C4 grass cover and PAR. However, the impact of Russian olive on biotic and abiotic components of the riparian ecosystem was conditioned by environmental context. For all response variables, models containing additional explanatory factors were more informative (had higher weighted AIC scores) than models containing Russian olive alone. For all response variables, the most informative models all contained Russian olive presence, cottonwood presence, and their interaction. For relative exotic species cover, the most informative models also included distance to and height above the thalweg and their interactions with Russian olive. The selected models for total cover, functional group composition, soil $\mathrm{N}$ concentration, and PAR were strongly supported as being the best of the candidate models (weighted AIC scores above 90\%; Table $1)$.

The selected models for richness and relative exotic cover in both years were not as strongly supported, with weighted AIC scores between 52 and $83 \%$. For each of these response variables, one other candidate model was included as an alternative (weighted AIC score above 10\%). The second most informative model for plant richness in 2010 contained only Russian olive presence as an explanatory variable. For plant richness in 2011, the second most informative model contained Russian olive presence, height above the thalweg, and their interaction. For proportion exotic cover in 2010 and 2011, the second most informative models included soil texture (\% sand) in addition to the terms in the most informative model (Table $1)$.

Biotic Response Variables: Plant Community Composition. Over both years, we found a total of 138 species over all plots. Of these, 99 were native, 31 were exotic, and 
Table 2. Mixed-model ANOVA of AIC-selected models for plant species richness, total cover, exotic plant cover, plant functional group composition in 2010 and 2011, PAR, and soil N described by the interaction of Russian olive, cottonwood canopy, distance to thalweg, and height above thalweg. For functional cover, all terms are interactions with functional group. Missing values (e.g., distance to thalweg for 2010 or 2011 cover) occur when an independent variable is not present in the AIC-selected model. ${ }^{a}$ Bold text indicates significant variables at $\alpha=0.05$ in the AIC-selected model for each response variable.

\begin{tabular}{|c|c|c|c|c|c|c|c|c|c|c|}
\hline Model term & $\begin{array}{l}\text { Total } \\
\text { cover } \\
2010\end{array}$ & $\begin{array}{l}\text { Total } \\
\text { cover } \\
2011\end{array}$ & $\begin{array}{l}\text { Rel. } \\
\text { exotic } \\
\text { cover } \\
2010\end{array}$ & $\begin{array}{l}\text { Rel. } \\
\text { exotic } \\
\text { cover } \\
2011\end{array}$ & $\begin{array}{l}\text { Functional } \\
\text { group } \\
\text { composition } \\
2010\end{array}$ & $\begin{array}{l}\text { Functional } \\
\text { group } \\
\text { composition } \\
2011\end{array}$ & $\begin{array}{c}\text { Richness } \\
2010\end{array}$ & $\begin{array}{c}\text { Richness } \\
2011\end{array}$ & PAR & Soil N \\
\hline \multicolumn{11}{|l|}{ Russian olive } \\
\hline$F$ & 7.94 & 1.85 & 15.72 & 12.94 & 9.14 & 14.31 & 0.02 & 10.32 & 251.29 & 29.32 \\
\hline $\mathrm{df}$ & 1,191 & 1,187 & 1,175 & 1,172 & $5,2,100$ & $5,2,082$ & 1,192 & 1,191 & 1,192 & $1,58.8$ \\
\hline $\mathrm{P}$ & $<0.01$ & 0.17 & $<0.01$ & $<0.01$ & $<0.01$ & $<0.01$ & 0.90 & $<0.01$ & $<0.01$ & $<0.01$ \\
\hline \multicolumn{11}{|l|}{ Cottonwood } \\
\hline$F$ & 27.78 & 34.66 & 0.34 & 0.82 & 36.35 & 35.88 & 4.29 & 4.92 & 10.26 & 0.98 \\
\hline $\mathrm{df}$ & 1,213 & 1,254 & 1,228 & 1,219 & $5,2,100$ & $5,2,082$ & 1,240 & 1,227 & 1,229 & $1,70.7$ \\
\hline $\mathrm{P}$ & $<0.01$ & $<0.01$ & 0.56 & 0.37 & $<0.01$ & $<0.01$ & 0.04 & 0.03 & $<0.01$ & 0.32 \\
\hline \multicolumn{11}{|c|}{ Russian olive* cottonwood } \\
\hline$F$ & 6.66 & 12.31 & 1.72 & 5.26 & 2.03 & 2.62 & 0.42 & 10.85 & 41.68 & 3.26 \\
\hline $\mathrm{df}$ & 1,203 & 1,195 & 1,164 & 1,160 & $5,2,100$ & $5,2,082$ & 1,204 & 1, 209 & 1,374 & $1,60.7$ \\
\hline $\mathrm{P}$ & 0.01 & $<0.01$ & 0.19 & 0.02 & 0.07 & 0.02 & 0.52 & $<0.01$ & $<0.01$ & 0.08 \\
\hline \multicolumn{11}{|c|}{ Distance to thalweg } \\
\hline$F$ & & & 2.18 & 7.85 & & & & & & \\
\hline $\mathrm{df}$ & - & - & 1,111 & 1,150 & - & - & - & - & - & - \\
\hline $\mathrm{P}$ & - & - & 0.14 & $<0.01$ & - & - & - & - & - & - \\
\hline \multicolumn{11}{|c|}{ Russian olive*distance to thalweg } \\
\hline$F$ & & & 1.16 & 0.69 & & & & & & \\
\hline $\mathrm{df}$ & - & - & 1,154 & 1,153 & - & - & - & - & - & - \\
\hline $\mathrm{P}$ & - & - & 0.28 & 0.41 & - & - & - & - & - & - \\
\hline \multicolumn{11}{|c|}{ Height above thalweg } \\
\hline$F$ & & & 2.55 & 0.90 & & & & & & \\
\hline $\mathrm{df}$ & - & - & 1,221 & 1,271 & - & - & - & - & - & - \\
\hline $\mathrm{P}$ & - & - & 0.11 & 0.34 & - & - & - & - & - & - \\
\hline \multicolumn{11}{|c|}{ Russian olive*height above thalweg } \\
\hline$F$ & & & 0.19 & 0.28 & & & & & & \\
\hline $\mathrm{df}$ & - & - & 1,192 & 1,188 & - & - & - & - & - & - \\
\hline $\mathrm{P}$ & - & - & 0.67 & 0.60 & - & - & - & - & - & - \\
\hline
\end{tabular}

${ }^{a}$ AIC, Akaike information criterion; PAR, photosynthetically active radiation; Rel., relative; df, degrees of freedom.

8 were only identified to genus and could not be unambiguously categorized as native or exotic. Reference plots contained a total of 122 species (91 native, 24 exotic, and 7 that were only identified to genus), whereas Russian olive plots contained a total of 111 species (72 native, 31 exotic, and 8 that were only identified to genus). Based on percent cover, the 10 most abundant species were Panicum virgatum L., Bromus inermis Leyss. spp. inermis, Ambrosia psilostachya DC., Elymus canadensis L., Nepeta cataria L., [Bassia scoparia (L.) A.J. Scott], Spartina pectinata Bosc ex Link, [Cirsium arvense (L.) Scop.], [Sporobolus cryptandrus (Torr.) A. Gray], and Bromus tectorum L. (full species list available in Appendix 1).
Based on a mixed-model ANOVA of the factors included in the AIC-selected most informative models, Russian olive presence had a significant effect on all biotic response variables except richness in 2010. The interaction between Russian olive and cottonwood canopy had a significant effect on total cover in 2010 and 2011, relative exotic cover in 2011, functional group composition in 2011 , and plant richness in 2011. For relative exotic cover in 2010 and 2011, the interaction of Russian olive with distance to thalweg and height above thalweg were significant (Table 2).

Russian olive had a strong influence on plant community composition, but the strength of that influence was generally reduced under a cottonwood canopy. Compared 
Table 3. The $t$ tests of differences between Russian olive and reference plot least square means underneath cottonwood canopy and in the open. Values for total cover and soil N have been back-transformed. Significant differences at $\alpha=0.05$ between Russian olive and reference plots are bold. ${ }^{a}$

\begin{tabular}{|c|c|c|c|c|c|c|c|c|c|c|}
\hline \multirow[b]{2}{*}{ Response variable } & \multicolumn{5}{|c|}{ Cottonwood } & \multicolumn{5}{|c|}{ Open } \\
\hline & $\begin{array}{l}\text { Russian olive } \\
\text { reference plots }\end{array}$ & SE & df & $t$ value & $\mathrm{P}$ value & $\begin{array}{l}\text { Russian olive } \\
\text { reference plots }\end{array}$ & SE & df & $t$ value & $\mathrm{P}$ value \\
\hline Total cover 2010 & -11.70 & 0.51 & 198 & -3.36 & $<0.01$ & -0.52 & 0.02 & 195 & -0.17 & 0.86 \\
\hline Total cover 2011 & -9.55 & 0.50 & 194 & -3.04 & $<0.01$ & 5.07 & 0.21 & 191 & 1.83 & 0.06 \\
\hline Rel. exotic cover 2010 & 19.99 & 4.70 & 159 & 4.25 & $<\mathbf{0 . 0 1}$ & 28.11 & 3.65 & 156 & 7.70 & $<0.01$ \\
\hline Richness 2010 & -0.15 & 0.30 & 199 & -0.48 & 0.63 & 0.10 & 0.22 & 195 & 0.43 & 0.66 \\
\hline Richness 2011 & -0.02 & 0.37 & 202 & -0.06 & 0.95 & 1.50 & 0.27 & 197 & 5.45 & $<0.01$ \\
\hline PAR & -25.91 & 4.46 & 202 & -5.81 & $<0.01$ & -61.93 & 3.32 & 197 & -18.65 & $<0.01$ \\
\hline Soil N & 15.35 & 1.24 & 56.7 & 2.47 & 0.02 & 39.61 & 1.23 & 63.3 & 5.27 & $<0.01$ \\
\hline
\end{tabular}

a Abbreviations: SE, standard error; df, degrees of freedom; Rel., relative; PAR, photosynthetically active radiation.

with reference plots, Russian olive plots had higher relative exotic cover (exotic/total cover), lower perennial C4 grass cover, and higher perennial forb cover (Table 3; Figures 2 and 3). Presence of a cottonwood canopy, however, significantly altered the impact of Russian olive for five of the eight vegetation variables measured over $2 \mathrm{yr}$ (Table 2). For example, in both 2010 and 2011, the presence of a cottonwood canopy reduced the increase in relative exotic cover attributable to Russian olive (Table 3).

The second-best models for exotic cover (weighted AIC $=33.3 \%$ for $2010,23.2 \%$ for 2011 ) included percent sand in addition to the variables included in the best model (Table 1). When sand was included, none of the variables and interactions in the model had a significant effect on relative exotic cover. This is likely the result of reduced sample size, because we did not measure soil texture on all plots. The second-best model for species richness in 2010 (weighted $\mathrm{AIC}=23.5 \%$ ) contained only Russian olive presence as an independent variable (Table 1). However, there was no significant effect of Russian olive in this model $\left(F_{1,192}=0.00, \mathrm{P}=0.95\right)$. In the alternative model for richness in 2011 (weighted AIC $=15.8 \%$ ), distance to thalweg had a significant effect $\left(F_{1,257}=4.51, \mathrm{P}=0.03\right)$, but its interaction with Russian olive $\left(F_{1,217}=0.00, \mathrm{P}=\right.$ $0.99)$ and Russian olive alone did not $\left(F_{1,201}=2.09, \mathrm{P}=\right.$ $0.15)$. In this model, the number of species per plot decreased as height above the thalweg increased $(-0.32 \pm$ 0.14 species plot ${ }^{-1} \mathrm{~m}^{-1}, t_{302}=-12.34, \mathrm{P}=0.02$ ).

Abiotic Response Variables: PAR and Available N. In the AIC-selected models for the abiotic response variables, Russian olive presence and the interaction of Russian olive and cottonwood canopy was significant for PAR, but only Russian olive presence was significant for soil $\mathrm{N}$ concentration (Table 2). Russian olive decreased PAR in the open and underneath cottonwood, but the effect was greater in the open (Table 3; Figure 4). In the open, Russian olive plots had less than one-third the PAR level of reference plots, whereas underneath cottonwood canopy, Russian olive plots had about one-half the PAR level of reference plots. However, Russian olive plots had similar PAR regardless of whether they were under cottonwood canopy or in the open $\left(t_{381}=1.29, \mathrm{P}=0.20\right)$, meaning the significant effect of cottonwood canopies on Russian olive impact on PAR was due to differences in reference plot PAR values. Russian olive increased available soil $\mathrm{N}$ most in open areas (Table 3; Figure 4). Under cottonwood, Russian olive plots had 1.7 times higher available soil $\mathrm{N}$ than reference plots, and they had 3.1 times higher available $\mathrm{N}$ in the open. Compared with Russian olive plots under cottonwood, Russian olive plots in the open had 1.7 times higher available soil $\mathrm{N}\left(t_{1,99.7}=-2.04, \mathrm{P}=0.04\right)$.

\section{Discussion}

This study demonstrates that Russian olive substantially impacts riparian plant communities, and that those impacts are conditioned by environmental factors within a heterogeneous riparian ecosystem. Specifically, the per capita impacts of Russian olive on the understory plant community (i.e., increased relative exotic cover, decreased perennial C4 grass cover, and increased perennial forb cover), PAR, and soil $\mathrm{N}$ were influenced primarily by presence or absence of cottonwood overstory canopy, with generally greater impacts in open areas outside of the cottonwood gallery forest. Understanding variations in the impact of single-plant invaders is important for determining the characteristics of ecosystems that make them most vulnerable to invasion-induced changes and for identifying 
2010
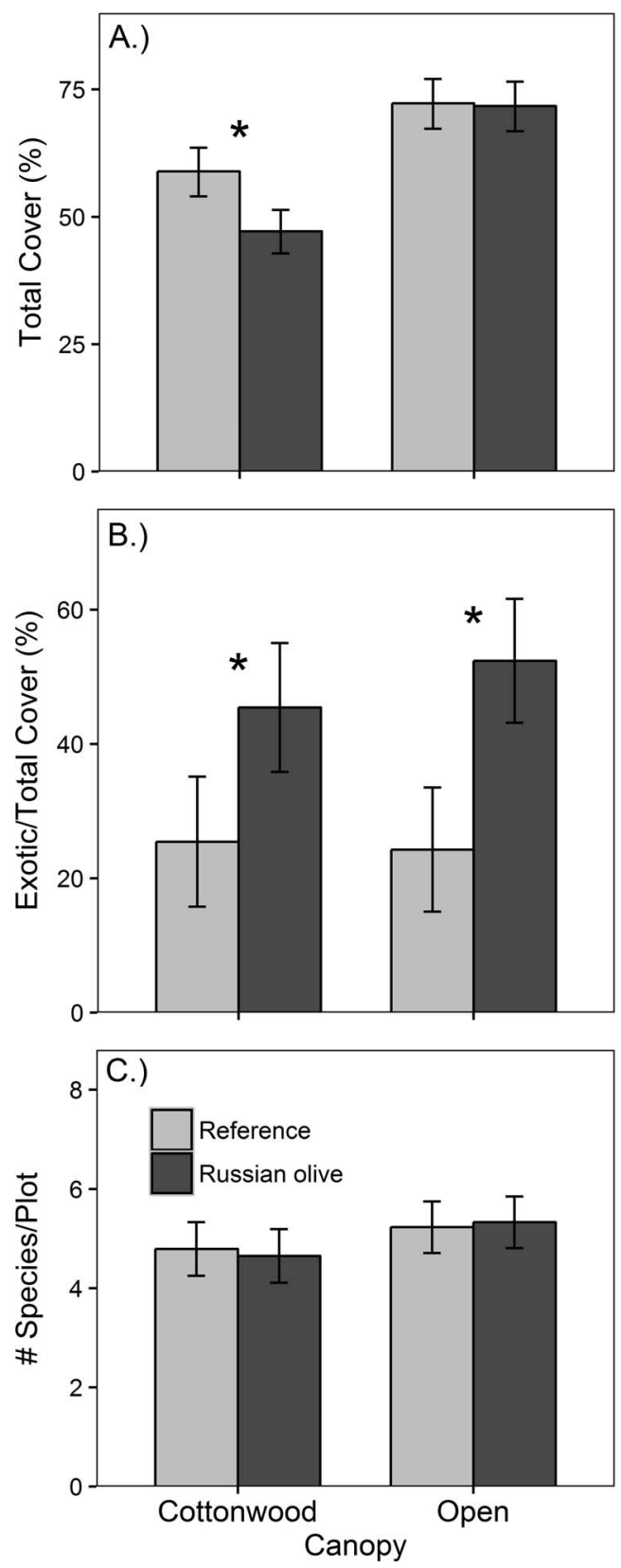

2011
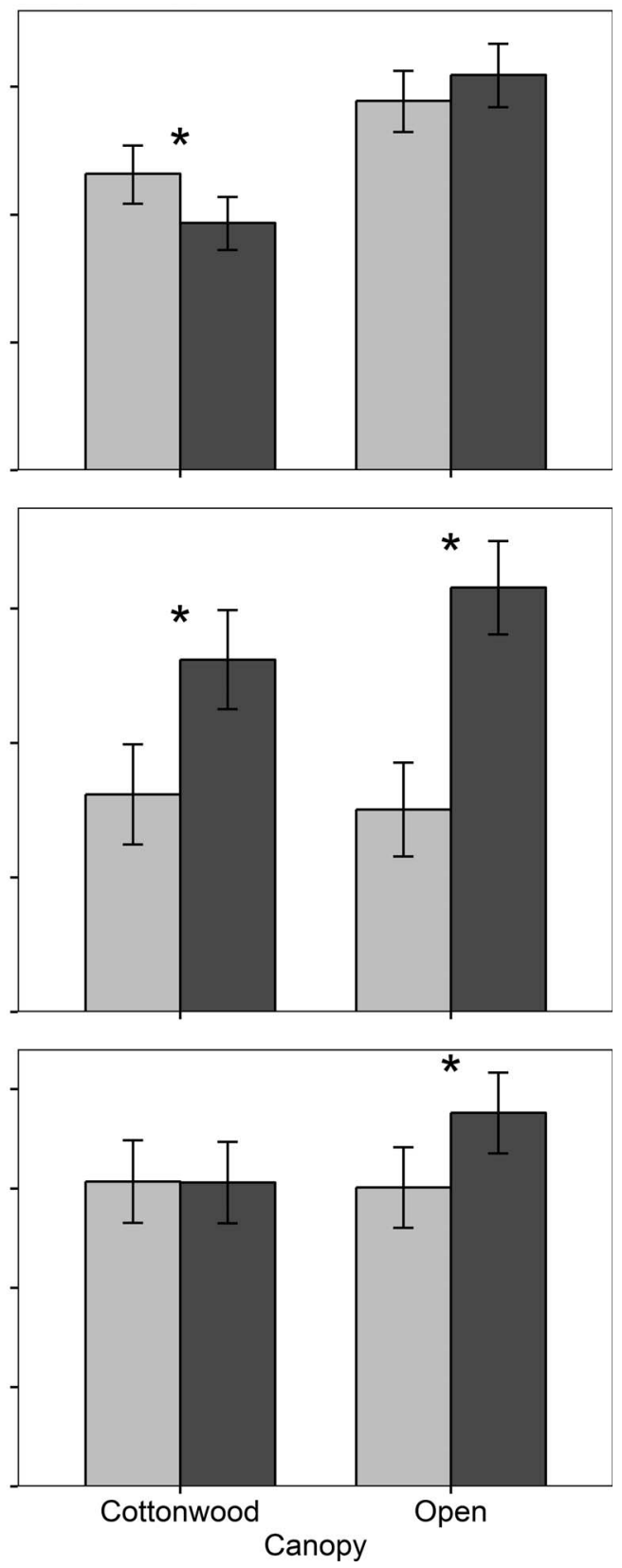

Figure 2. Least squares means \pm SE for biotic response variables measured in August 2010 and 2011, as conditioned by presence/ absence of Russian olive and cottonwood forest overstory: total plant cover (A), proportion exotic cover (B), plant species richness (C). Russian olive plots were located underneath a Russian olive canopy, and reference plots were located at least $3 \mathrm{~m}$ away from a Russian olive canopy drip line. Cottonwood plots occurred underneath the cottonwood gallery forest overstory, and open plots did not. Values in plots A and C have been back-transformed. * Indicates significant difference $(\alpha=0.05)$ between Russian olive and reference plots.

the specific combinations of invader traits and ecosystem characteristics that yield the greatest impact (Ehrenfeld 2003; Hulme et al. 2013).

Our results highlight the importance of native broadleaf pioneer tree species (i.e., cottonwoods and willows) in dampening invader impacts in western U.S. riparian ecosystems. Under cottonwood canopies, Russian olive had less effect on plant community composition, PAR, and available soil $\mathrm{N}$ than in open areas. A reduction in total vegetation cover was the only effect of Russian olive that occurred under cottonwood and not in the open. Previous studies have documented the critical role of riparian 

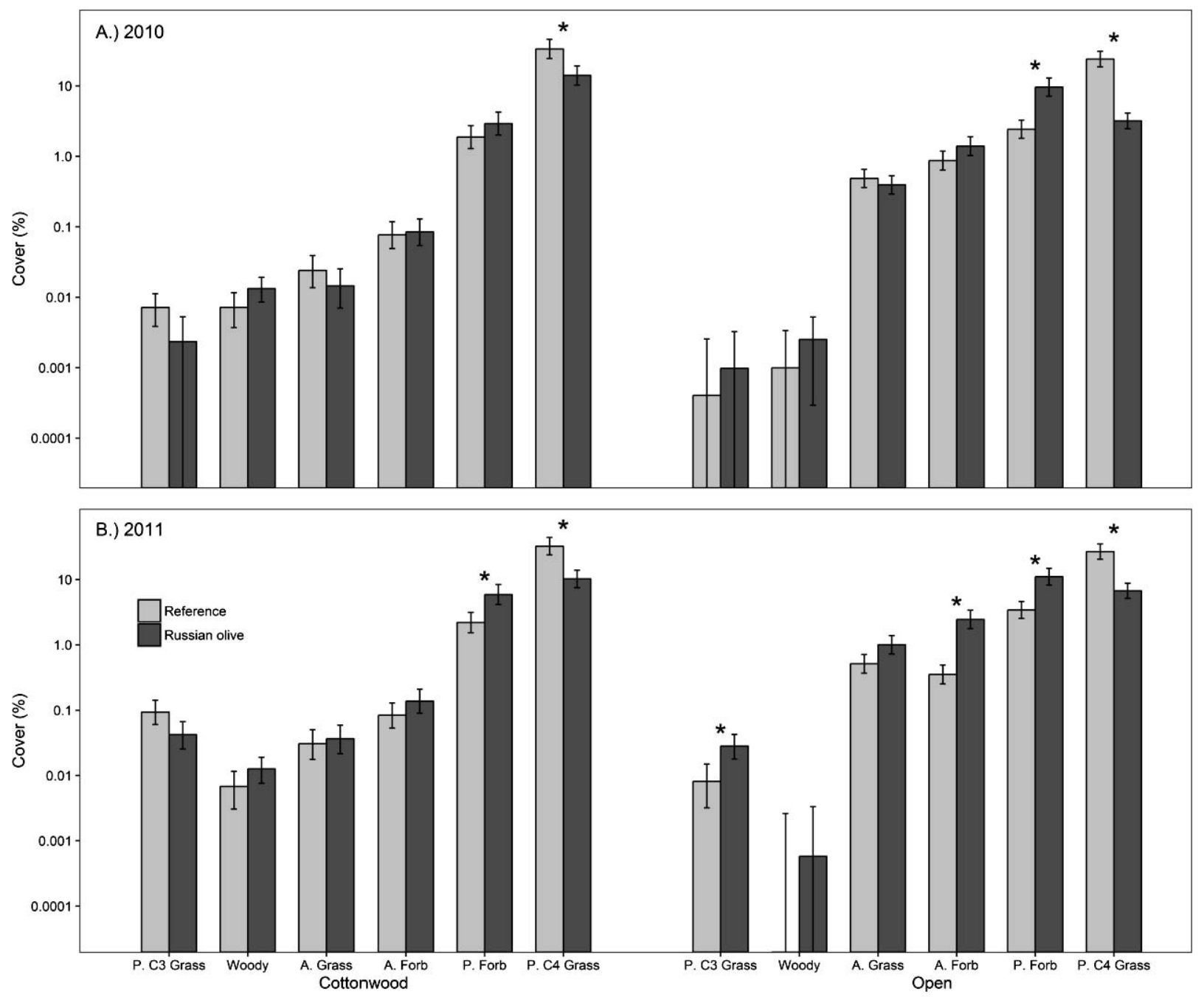

Figure 3. Least squares means \pm SE for plant functional group cover measured in August 2010 (A) and 2011 (B), as conditioned by presence/absence of Russian olive and cottonwood forest overstory. Values have been back-transformed. * Indicates significant difference $(\alpha=0.05)$ between Russian olive and reference plots. Note: $y$ axis is log scale to show functional groups with lower cover.

cottonwoods in providing habitat for wildlife (Sedgwick and Knopf 1986) and reducing bank erosion (Henderson 1986) and have raised concerns about the conservation status of cottonwood-willow-dominated ecosystems in arid regions (Braatne et al. 1996). We add to the understanding of the cottonwood's importance by demonstrating that riparian gallery forests also diminish the impacts of a widespread and abundant nonnative tree species.

The reduction in per capita impacts of Russian olive under the cottonwood canopy was likely caused by the smaller size and lower growth rates of Russian olive individuals growing in this environment. Russian olive trees had greater basal diameters in open areas than under cottonwood canopies at our study sites $(40.1 \pm 20.8 \mathrm{~cm}$ vs. $29.2 \pm 12.4 \mathrm{~cm}$; G. Tuttle, unpublished data). The larger size of Russian olive individuals in the open could have been due either to earlier establishment in these areas or to faster growth there. However, Katz et al. (2005) found no evidence that Russian olive had established earlier in open habitats than in the cottonwood understory in our study area. Thus, the larger size of Russian olive individuals in the open was likely due to faster growth rates where light levels were 1.5 times higher than under the cottonwood canopy. This idea is supported by Shafroth et al. (1995), who found greater biomass of Russian olive seedlings grown in the sun compared with the shade in an experimental study. Faster growth would lead to denser and larger Russian olive canopies and more strongly reduced PAR levels in the open, as we observed. Better conditions for photosynthesis in the open would also lead to increased $\mathrm{N}$ fixation (Vitousek et al. 2002) and higher $\mathrm{N}$ concentrations in Russian olive foliage, which is consistent with our observation of higher soil $\mathrm{N}$ under Russian olive in the open than under a cottonwood canopy. Thus, 

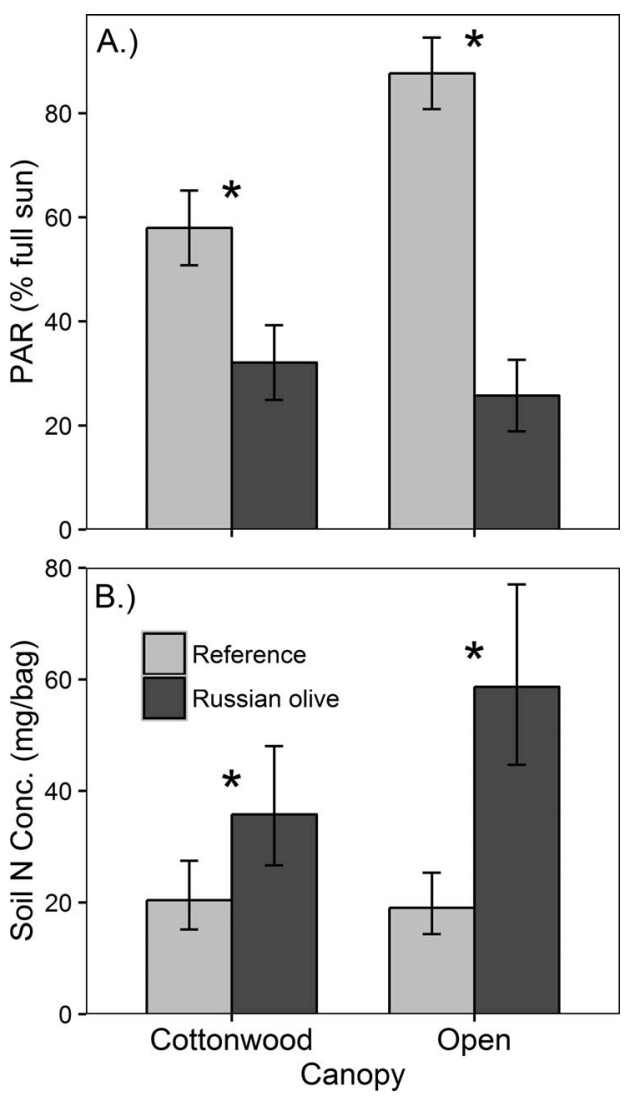

Figure 4. Least squares means \pm SE for abiotic response variables, as conditioned by presence/absence of Russian olive and cottonwood forest overstory. (A) Photosynthetically active radiation (PAR) in August 2010; (B) inorganic soil N concentration (August 2010 through August 2011). Plot locations are described in Figure 3. Values in B have been back-transformed. ${ }^{*}$ Indicates significant difference $(\alpha=0.05)$ between Russian olive and reference plots.

enhanced growth and performance of Russian olive in open habitats was likely responsible for its greater impacts on riparian abiotic and biotic conditions.

An increase in available soil $\mathrm{N}$ likely drove the increase in relative exotic cover underneath Russian olive, because the highest proportion of exotic cover occurred under Russian olive in open areas where available soil $\mathrm{N}$ was also the highest. Increased $\mathrm{N}$ availability may benefit fastgrowing exotics at the expense of slow-growing natives adapted to low resource availability (Chapin 1980). In experimental studies, elevated soil $\mathrm{N}$ has been shown to increase the abundance of exotic species (e.g., Brooks 2003; Paschke et al. 2000), likely because the flux of unused resources can be exploited by invaders (Davis et al. 2000). However, DeCant (2008) argued that $\mathrm{N}$ enhancement by Russian olive was unlikely to facilitate exotic plant invasion on the Rio Grande floodplain, because soil microbial growth experiments showed limitation by $\mathrm{C}$, not $\mathrm{N}$. $\mathrm{He}$ suggested instead that the effects of shading by Russian olive on PAR and soil moisture may be more responsible for changes in community composition. DeCant's hypothesis seems implausible for our study sites because shading by cottonwood did not produce the increase in exotic species that we observed under Russian olive. Our results suggest that an "invasional meltdown" is occurring (Simberloff and Von Holle 1999), because Russian olive appears to facilitate the invasion of other exotic species, particularly outside of the cottonwood canopy.

As in other riparian systems, variations in soil texture and horizontal and vertical distance from the river influenced biotic and abiotic conditions at our study sites, although these effects were less important than the effects of Russian olive and cottonwood. For example, differences in soil texture, soil moisture, flooding frequency, and soil $\mathrm{N}$ concentrations, driven largely by flooding disturbance history, had large impacts on plant community composition along the Snake River in Idaho (Merigliano 2005). In our study, the effect of $\mathrm{N}$ on plant community composition may have been complicated by differences in soil texture (Bechtold and Naiman 2006), denitrification rates, and plant $\mathrm{N}$ uptake among riparian geomorphic surfaces (Pinay et al. 1995). However, soil texture (\% sand) was not included as an explanatory factor in any of our best models and was only included in two second-best models (exotic cover in 2010 and 2011). This result supports DeCant (2008), who found that in riparian areas invaded by Russian olive, variation in available soil $\mathrm{N}$ was best explained by Russian olive presence and not soil texture. Ultimately, the presence or absence of Russian olive and cottonwood were the strongest determinants of riparian abiotic and biotic conditions in our study plots, with riparian soil and geomorphic factors playing relatively minor roles.

\section{Acknowledgments}

Funding for this research was provided by the Three Rivers Alliance. The Nature Conservancy also provided support for this work through the Nebraska Chapter's J. E. Weaver Competitive Grants Program. We thank Fred Raish for helping design our study and R. and G. Brittain for allowing access to their property. Thanks also to J. Hardin, S. Randall, P. Martin, M. Lewis, D. Richardson, C. Carlson, and Z. Peterson for assistance in the field and laboratory. Any use of trade, firm, or product names is for descriptive purposes only and does not imply endorsement by the U.S. Government.

\section{Literature Cited}

Albers HJ, Fischer C, Sanchirico JN (2010) Invasive species management in a spatially heterogeneous world: effects of uniform policies. Resour Energy Econ 32:483-499 
Bagstad KJ, Lite SJ, Stromberg JC (2006) Vegetation, soils, and hydrogeomorphology of riparian patch types of a dryland river. West N Am Nat 66:23-44

Barney JN, Tekiela DR, Dollete E, Tomasek B (2013) What is the "real" impact of invasive plant species. Front Ecol Env 11:322-329

Bechtold JS, Naiman RJ (2006) Soil nitrogen mineralization potential across a riparian toposequence in a semi-arid savanna. Soil Biol Biochem 38:1325-1333

Binkley D (1984) Ion exchange resin bags: factors affecting estimates of nitrogen availability. Soil Sci Soc Am J 48:1181-1184

Boggs K, Weaver T (1994) Changes in vegetation and nutrient pools during riparian succession. Wetlands 14:98-109

Bouyoucos GJ (1936) Directions for making mechanical analyses of soils by the hydrometer method. Soil Sci 42:225-229

Braatne JH, Rood SB, Heilman PE (1996) Life history, ecology and conservation of riparian cottonwoods in North America. Pages 17-67 in Stettler RF, Bradshaw HD, Heilman PE, Hinckly TM, eds. Biology of Populus. Ottawa, ON: NRC Research Press

Brooks M (2003) Effects of increased soil nitrogen on the dominance of alien annual plants in the Mojave Desert. J Appl Ecol 40:344-353

Burnham KP, Anderson DR (2002) Model Selection and Multi-modal Inference: A Practical Information-Theoretic Approach, 2nd edn. New York: Springer-Verlag

Castro-Díez P, Godoy O, Alonso A, Gallardo A, Saldaña A (2014) What explains variation in the impacts of exotic plant invasions on the nitrogen cycle? A meta-analysis. Ecol Lett 17:1-12

Chapin FS III (1980) The mineral nutrition of wild plants. Annu Rev Ecol Syst 11:233-260

Collette LKD, Pither J (2015) Russian-olive (Elaeagnus angustifolia) biology and ecology and its potential to invade northern North American riparian ecosystems. Invasive Plant Sci Manag 8:1-14

Colorado Climate Center (2010) Monthly Climate Data for Burlington. Colorado State University. http://cccatmoscolostateedu/cgi-bin/ mlydbpl. Accessed July 29, 2014

Crooks JA (2002) Characterizing ecosystem-level consequences of biological invasions: the role of ecosystem engineers. Oikos 97:153-166

D'Antonio CM, Tunison JT, Loh RK (2000) Variation in the impact of exotic grasses on native plant composition in relation to fire across an elevation gradient in Hawaii. Austral Ecol 25:507-522

Davis MA, Grime JP, Thompson K (2000) Fluctuating resources in plant communities: a general theory of invisibility. J Ecol 88:528534

DeCant JP (2008) Russian olive, Elaeagnus angustifolia, alters patterns in soil nitrogen pools along the Rio Grande River, New Mexico, USA. Wetlands 28:896-904

Ehrenfeld JG (2003) Effects of exotic plant invasions on soil nutrient cycling process. Ecosystems 6:503-523

Ehrenfeld JG (2010) Ecosystem consequences of biological invasions. Annu Rev Ecol Syst 41:59-80

Follstad Shah JJ, Harner MJ, Tibbets TM (2010) Elaeagnus angustifolia elevates soil inorganic nitrogen pools in riparian ecosystems. Ecosystems 13:46-61

Friedman JM, Gregor TA, Shafroth PB, Scott ML, Merigliano MF, Freehling MD, Griffin ER (2005) Dominance of non-native riparian trees in western USA. Biol Invasions 7:747-751

Friedman JM, Osterkamp WR, Lewis WM (1996) Channel narrowing and vegetation development following a Great Plains flood. Ecology $77: 2167-2181$
Gaertner M, Biggs R, Beest MT, Hui C, Molofsky J, Richardson DM (2014) Invasive plants as drivers of regime shifts: identifying high priority invaders that alter feedback relationships. Divers Distrib 20:733-744

Gotelli NJ, Ellison AM (2004) A Primer of Ecological Statistics. Sunderland, MA: Sinauer Associates

Henderson JE (1986) Environmental designs for streambank protection projects. J Am Water Resour Assoc 22:549-558

Holland JB (2006) Estimating Genotypic Correlations and Their Standard Errors Using Multivariate Restricted Maximum Likelihood Estimation with SAS Proc MIXED. Crop Sci 46:642-654

Hulme PE, Pyšek P, Jarosik V, Pergl J, Schaffner U, Vilà M (2013) Bias and error in understanding plant invasion impacts. Trends Ecol Evol 28:212-218

Jarnevich CS, Reynolds LV (2011) Challenges of predicting the potential distribution of a slow-spreading invader: a habitat suitability map for an invasive riparian tree. Biol Invasions 13:153-63

Johnson JB, Omland KS (2004) Model selection in ecology and evolution. Trends Ecol Evol 19:101-107

Katz GL, Friedman JM, Beatty SW (2001) Effects of physical disturbance and granivory on establishment of native and alien riparian trees in Colorado, USA. Divers Distrib 7:1-14

Katz GL, Friedman JM, Beatty SW (2005) Delayed effects of flood control on a flood-dependent riparian forest. Ecol Appl 15:10191035

Katz GL, Shafroth PB (2003) Biology, ecology and management of Elaeagnus angustifolia L (Russian olive) in western North America. Wetlands 23:763-777

Kolar CS, Lodge DM (2001) Progress in invasion biology: predicting invaders. Trends Ecol Evol 16:199-204

Levine JM (2000) Species diversity and biological invasions: relating local process to community pattern. Science 288:852-854

Liao C, Peng R, Luo Y, Zhou X, Wu X, Fang C, Chen J, Li B (2008) Altered ecosystem carbon and nitrogen cycles by plant invasion: a meta-analysis. New Phytol 177:706-714

Lyon J, Gross NM (2005) Patterns of plant diversity and plantenvironmental relationships across three riparian corridors. For Ecol Manage 204:267-278

Maron JL, Marler M. 2008. Effects of native species diversity and resource additions on invader impact. Am Nat 172 (Suppl 1):S18S33

McShane R, Auerbach D, Friedman JM, Auble GT, Shafroth PB, Merigliano MF, Scott ML, Poff L (2015) Distribution of invasive and native riparian woody plants across the western USA in relation to climate, river flow, floodplain geometry and patterns of introduction. Ecography 38:1-12

Melbourne BA, Cornell HV, Davies KF, Dugaw CJ, Elmendorf S, Freestone AL, Hall RJ, Harrison S, Hastings A, Holland M, Holyoak M, Lambrinos J, Moore K, Yokomizo H (2007) Invasion in a heterogeneous world: resistance, coexistence or hostile takeover? Ecol Lett 10:77-94

Merigliano MF (2005) Cottonwood understory zonation and its relation to floodplain stratigraphy. Wetlands 25:356-374

Nagler PL, Glenn EP, Jarnevich CS, Shafroth PB (2011) Distribution and abundance of saltcedar and Russian olive in the western United States. Crit Rev Plant Sci 30:508-523

Naiman, RJ, DeCamps H, Pollock M (1993) The role of riparian corridors in maintaining regional biodiversity. Ecol Appl 3:209-212 
Nakamura F, Yajima T, Kikuchi S (1997) Structure and composition of riparian forests with special reference to geomorphic site conditions along the Tokachi River, northern Japan. Plant Ecol 133:209-219

O'Meara S, Larsen D, Owens C (2010) Methods to control saltcedar and Russian olive. Pages 65-102 in Shafroth PB, Brown CA, Merritt DM, eds. Saltcedar and Russian Olive Control Demonstration Act Science Assessment. Reston, VA: U.S. Geological Survey

Osterkamp WR, Fenton MM, Gustavson TC, Hadley RF, Holliday VT, Morrison RB, Toy TJ (1987) Great Plains. Pages 163-210 in Graf WL, ed. Geomorphic Systems of North America. Boulder, CO: Geological Society of America

Parker IM, Simberloff D, Lonsdale WM, Goodell K, Wonham M, Kareiva PM, Williamson MH, Von Holle B, Moyle PB Byers JE, Goldwasser L (1999) Impact: toward a framework for understanding the ecological effects of invaders. Biol Invasions 1:3-19

Paschke MW, McLendon T, Redente EF (2000) Nitrogen availability and old-field succession in a shortgrass steppe. Ecosystems 3:144-158

Patten DT (1998) Riparian ecosystems of semi-arid North America: diversity and human impacts. Wetland 18:498-512

Pearson DE, Ortega YK, Runyon JB, Butler JL (2016) Secondary invasion: the bane of weed management. Biol Conserv 197:8-17

Pinay G, Ruffinoni C, Fabre A (1995) Nitrogen cycling in two riparian forest soils under different geomorphic conditions. Biogeochemistry 30:9-29

Pyšek P, Jarosik V, Hulme PE, Pergl J, Hejda M, Shaffner U, Vilà M (2012) A global assessment of invasive plant impacts on resident species, communities and ecosystems: the interaction of impact measures, invading species' traits and environment. Glob Change Biol 18:1725-1737

Reynolds LV, Cooper DJ (2011) Ecosystem response to removal of exotic riparian shrubs and a transition to upland vegetation. Plant Ecol 212:1243-1261

Ricketts TH, Dinerstein E, Olson DM, Loucks CJ, Eichbaum W, DellaSala DA, Kavanagh K, Hedao P, Hurley P, Carney K, Abell R, Walters S (1999) Terrestrial Ecoregions of North America: A Conservation Assessment. Washington, DC: Island Press

Rood SB, Braatne JH, Goater LA (2010) Favorable fragmentation: river reservoirs can impede downstream expansion of riparian weeds. Ecol Appl 20:1664-1677

Rosenberg NJ (1986) Climate of the Great Plains region of the United States. Gt Plains Q 7:22-32

Scott NA, Saggar S, McIntosh PD (2001) Biogeochemical impact of Hieracium invasion in New Zealand's grazed tussock grasslands: sustainability implications. Ecol Appl 11:1311-1322
Sedgwick JA, Knopf FL (1986) Cavity-nesting birds and the cavity-tree resource in plains cottonwood bottomlands. J Wildlife Mange 50:247-252

Shafroth PB, Auble GT, Scott ML (1995) Germination and establishment of the native plains cottonwood (Populus deltoides Marshall subsp monilifera) and the exotic Russian-olive (Elaeagnus angustifolia L). Conserv Biol 9:1169-1175

Shaw RB (2008) Grasses of Colorado. Boulder, CO: University Press of Colorado

Simberloff D, Von Holle B (1999) Positive interactions of nonindigenous species: invasional meltdown? Biol Invasions 1:21-32

Simons SB, Seastedt TR (1999) Decomposition and nitrogen release from foliage of cottonwood (Populus deltoids) and Russian-olive (Elaeagnus angustifolia) in a riparian ecosystem. Southwest Nat 44:256-260.

Stohlgren TJ, Barnett DT, Kartesz JT (2003) The rich get richer: patterns of plant invasions in the United States. Front Ecol Environ $1: 11-14$

Strayer DL (2012) Eight questions about invasions and ecosystem functioning. Ecol Lett 15:1199-1210

Toner M, Keddy P (1997) River hydrology and riparian wetlands: a predictive model for ecological assembly. Ecol Appl 7:236-246

[USDA NRCS] U.S. Department of Agriculture Natural Resources Conservation Service (2013) The PLANTS Database. National Plant Data Team, Greensboro, NC. http://plants.usda.gov. Accessed July 18,2014

Vilà M, Espinar JL, Hejda M, Hulme PE, Jarosik V, Maron JL, Pergl J, Schaffner U, Sun Y, Pyšek P (2011) Ecological impacts of invasive alien plants: meta-analysis of their effects on species, communities and ecosystems. Ecol Lett 14:702-708

Vitousek, PM, Cassman K, Cleveland C, Crews T, Field CB, Grimm NB, Howarth RW, Marino R, Martinelli L, Rastetter EB, Sprent JI (2002) Towards an ecological understanding of biological nitrogen fixation. Biogeochemistry 57/58:1-45

Vought LBM, Dahl J, Pedersen CL, Lacoursiere JO (1994) Nutrient retention in riparian ecotones. Ambio 23:342-348

Weber WA, Wittmann RC (2001) Colorado Flora: Eastern Slope. Boulder, CO: University Press of Colorado

Wintle BC, Kirkpatrick JB (2007) The response of riparian vegetation to flood-maintained habitat heterogeneity. Austral Ecol 32:592-599

Received May 25, 2016, and approved October 11, 2016.

Associate Editor for this paper: Edith B. Allen, University of California, Riverside. 


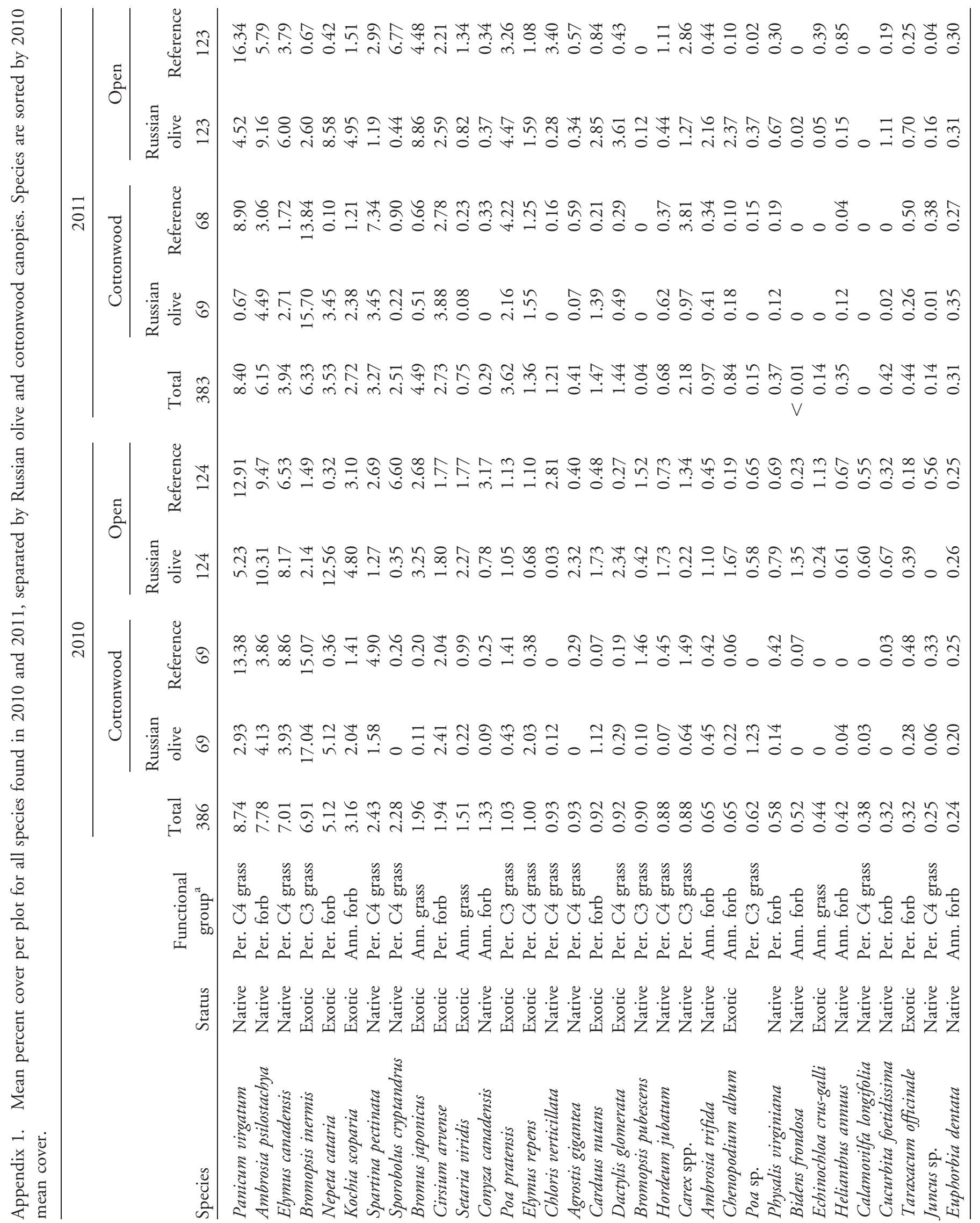

Tuttle et al: Russian olive impacts • 285 


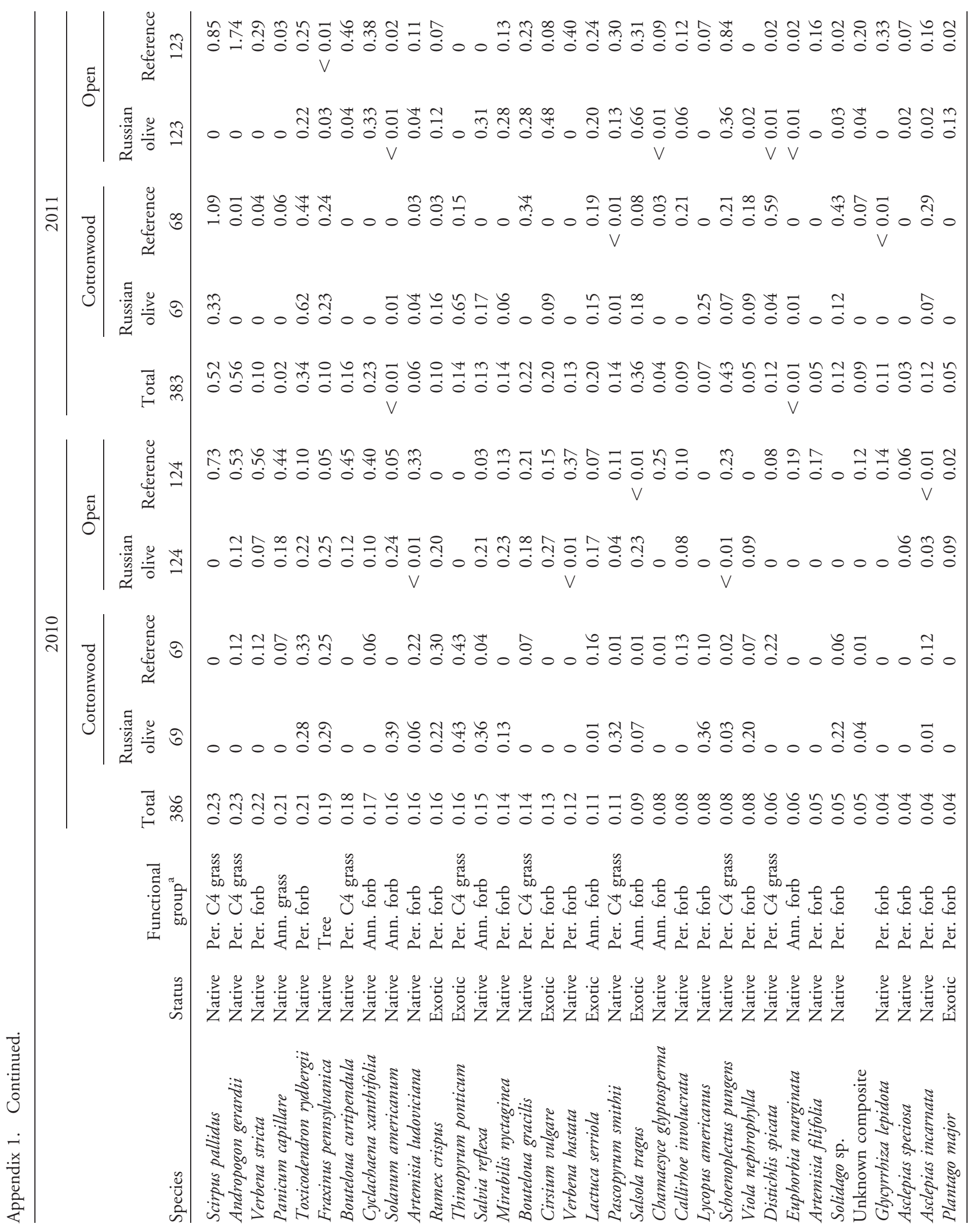

286 - Invasive Plant Science and Management 9, October-December 2016 


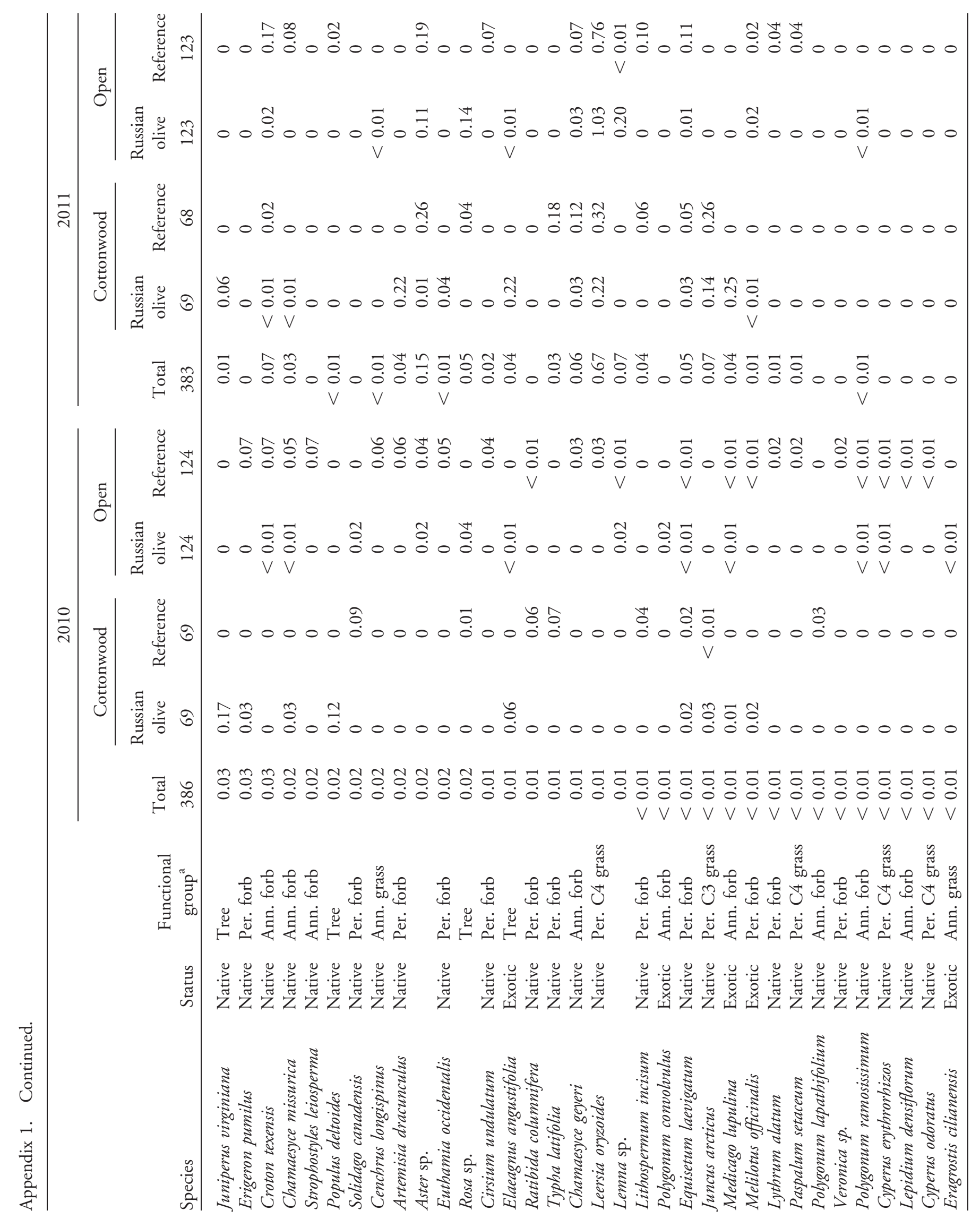

Tuttle et al: Russian olive impacts • 287 


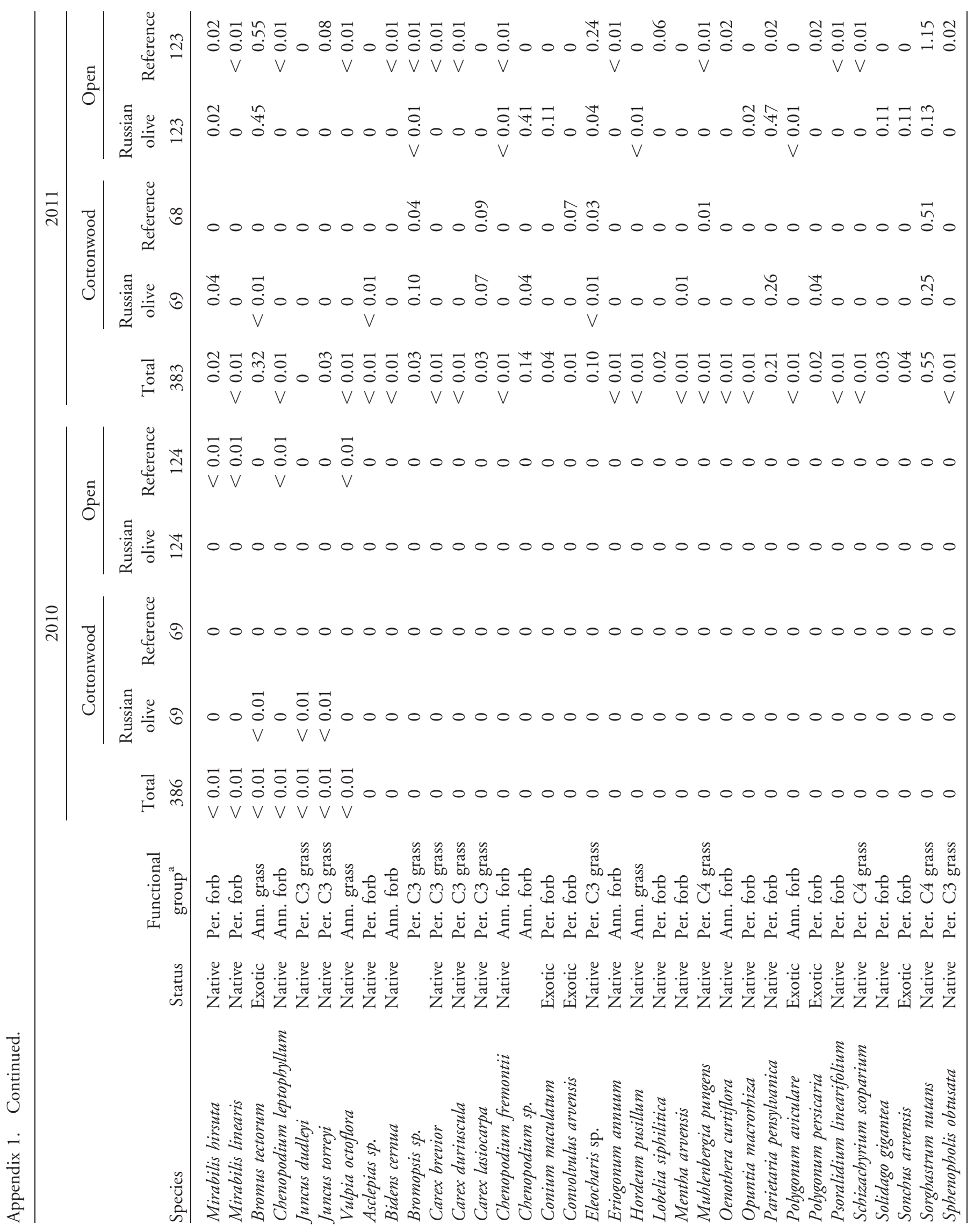




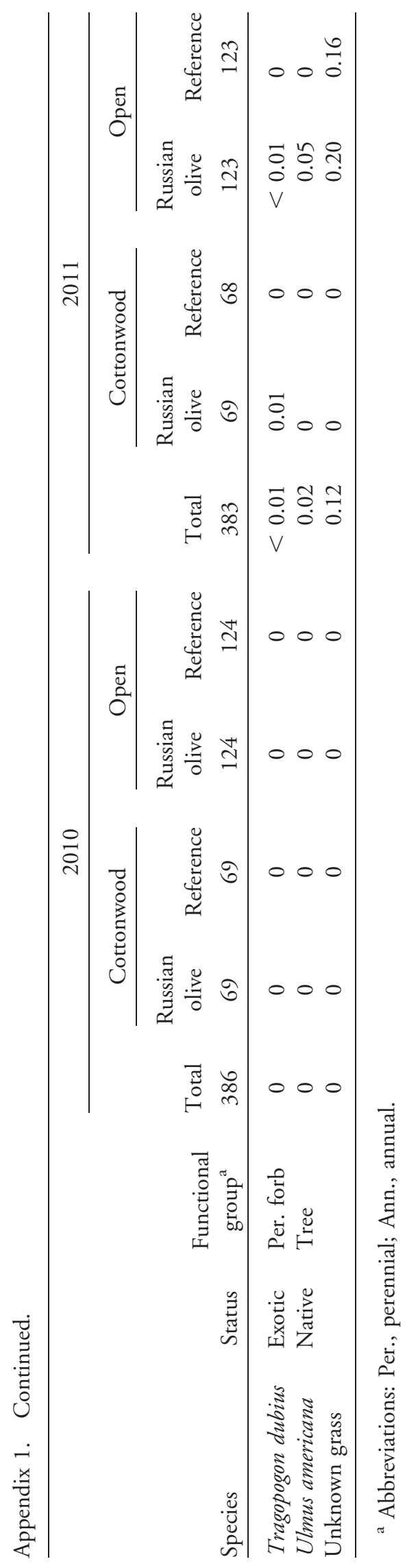

